\title{
Nutritional and Antioxidant Properties of Mango Juice and Aloe Vera Gel and their Effect on Diabetic Rats
}

\author{
Dina A. Anwar 1 (D), Heba R. Eid 1 (D), Ghadir A. El-Chaghaby 1,*(D) \\ 1 Regional Centre for Food and Feed, Agricultural Research Centre, Giza, Egypt; dinaanwar351@yahoo.com (D.A.A.); \\ heba.eed.1977@gmail.com (H.R.E); ghadiraly@yahoo.com (G.E.C.); \\ * Correspondence: ghadiraly@yahoo.com;
}

Scopus Author ID 24576282400

Received: 17.07.2020; Revised: 14.08.2020; Accepted: 16.08.2020; Published: 19.08.2020

\begin{abstract}
Aloe vera gel contains several vitamins and minerals, which make it rich in antioxidants and aid in managing different chronic conditions. Aloe vera, along with other fruits, is used to produce many fruit beverages. Therefore, the present work was designed to investigate effects on the sensory, nutritional, and antioxidant properties of the juice from various combinations of Aloe gel (7.5, 15, and 25 percent) with mango juice. Some biochemical parameters of streptozotocin-induced diabetic rats were also recorded for the effects of aloe gel, mango juice, and their combination. Sensory tests showed lower acceptability for juices with a content of 25 percent Aloe vera, while other scores obtained were good and deemed satisfactory. Calcium and chromium content in 25 percent aloe vera gel treatment was significantly $(\mathrm{p}<0.05)$ highest for mineral content, while phosphorus, potassium, and magnesium content were lower compared to other treatments. Results also showed that mango juice content of the antioxidant activity, phenols, and flavonoids increased with rising gel concentration in the blends. The administration of aloe-mango juice has resulted in a significant decrease in serum glucose and total cholesterol compared with other diabetic groups. A significant decrease in serum levels of AST, ALT, and ALP in animals receiving Aloe-mango juice relative to mango juice group was observed. Furthermore, Aloe-mango juice treatment ameliorated the oxidative stress as demonstrated by a substantial decrease in the serum MDA level in the treated group as opposed to the diabetic mango juice group. These findings of the present investigation support the use of Aloe gel for elevating the nutritional properties of the supplemented juices; it can be recommended to consume these juices as part of a healthy diet, especially for diabetic persons.
\end{abstract}

Keywords: Aloe vera; mango juice; antioxidants; nutritional value; anti-diabetic.

(C) 2020 by the authors. This article is an open-access article distributed under the terms and conditions of the Creative Commons Attribution (CC BY) license (https://creativecommons.org/licenses/by/4.0/).

\section{Introduction}

Aloe vera, a desert plant that has a very popular herbal remedy, belongs to the family Aloeaceae [1]. Aloe vera gel is the translucent mucilaginous gel present in the parenchymal cells. It contains extremely nutritious bioactive phytochemicals comprising anthraquinones, alkaloids, fats, glycoproteins, fatty acids, amino acids, nutrients, minerals, enzymes, and polysaccharides [2] as well as certain compounds with anti-diabetic function [3,4].

All age groups in society enjoy fruit drinks. Mixed drinks are a good alternative to develop new products with more benefits of taste, nutrition, and medicinal properties [5]. Aloe vera gel has been recommended for use in blended beverage formulations. Aloe Vera global drinks markets expanded at a pace of 9.6 percent over the period 2016 - 2020 [6]. Mango (Mangifera indica L.) is part of the Anacardiaceae family. Mango is considered an outstanding 
table fruit; it is a rich source of carbohydrate alongside vitamins A and C. It has also been reported that mango flesh has antioxidant and free radical scavenging properties, which reduce lipid peroxidation and boost antioxidant enzymes against isoproterenol [7]. In addition, mango juice is preferable to many people, but it's important to know the composition of fruits in the diet of diabetic patients.

Diabetes prevalence is growing rapidly across the world and is now recognized as one of the key threats to human health [8]. Changes in lifestyle, along with pharmacotherapy and patient education, are successful therapies for type 2 diabetes patients [9]. Diabetic patients have an increased risk of cardiovascular disease [10] and Alzheimer's disease [11]. In addition to the elevated risk of developing multiple cancers due to abnormal metabolism-induced immunological disorders [12], for example, it increases the risk of liver, pancreatic and endometrial cancers and 20-50 percent increase the risk of colorectal, breast and bladder cancers [13]. Patients with long-standing diabetes present various complications, such as neuropathies and multiple metabolic pathways, such as oxidation stress and hexosaminepathway [14]. Nature is an excellent source of anti-diabetic medicines [15], and plants are valuable dietary supplements to boost blood glucose regulation and avoid long term complications in type 2 diabetes [16]. The use of medicinal plants in the management of diabetes mellitus has been prevalent in many societies for a long time [17]

To prevent and treat acute and long-term complications of diabetes, related conditions and concomitant disorders, nutritional therapy is a means of sustaining or enhancing the quality of life as well as nutritional and physiological health [18]. This research was therefore undertaken to determine the nutritional and antioxidant properties of mango juice and aloe vera gel and to investigate the impact of mango juice supplemented with aloe vera gel on the diabetic rat (in vivo) biochemical parameters in the blood.

\section{Materials and Methods}

\subsection{Aloe vera leaf gel and Mango fruits.}

Fresh Aloe vera leaf gel and mango fruits from "Keitt" variety were purchased from locally available stores in EGYPT. The gel was kept in amber jars at $4{ }^{\circ} \mathrm{C}$ until subsequently used. Mango fruits were washed, peeled, and cut into small cubes, then placed in plastic bags and kept freeze.

\subsection{Preparation of mango juice supplemented with aloe vera gel.}

Mango cubes and aloe vera gel were blended either individually or in combination to obtain the different juices used in the experiment as follows:

T1: Mango juice $+0 \%$ Aloe vera gel

T2: Mango juice $+7.5 \%$ Aloe vera gel

T3: Mango juice $+15 \%$ Aloe vera gel

T4: Mango juice $+25 \%$ Aloe vera gel

After blending, the temperature of the juice was raised up to $80^{\circ} \mathrm{C}$ for two minutes; then, the juice was bottled in glass jars and stored at $4{ }^{\circ} \mathrm{C}$ until used.

The juices prepared from each combination blend were evaluated on a 10-point hedonic scale by a panel of trained judges for their organoleptic quality included taste, color, odor, and consistency, as described by [19] to find out the best combination of mango pulp and Aloe vera gel for juice preparation. 


\subsection{Chemical analysis.}

\subsubsection{Total flavonoids content.}

The aluminum chloride method was used to determine total flavonoid content by using Quercetin as standard [20]. The results were expressed as milligram Quercetin equivalent per 100 milliliters (mg QE/100 ml).

\subsubsection{Total phenols content.}

Total phenolic compounds in the different samples were determined by the FolinCiocalteu method [21] using gallic acid as standard. The results were expressed as milligram gallic acid equivalent per 100 milliliters (mg GAE/ $100 \mathrm{ml}$ ).

\subsubsection{Total antioxidant capacity.}

The total antioxidant capacity of the samples was determined using the phosphomolebdenum method [22] using ascorbic acid as standard. The results were expressed as milligram ascorbic acid equivalent per 100 milliliters (mg AAE / $100 \mathrm{ml}$ ).

\subsubsection{Minerals content.}

Minerals $(\mathrm{K}, \mathrm{Cr}$, and $\mathrm{Mg}$ ) in the different samples were determined using atomic absorption spectrophotometer (Model 2380, Perkin Elmer, Inc., Norwalk, CT, USA); Calcium was determined by titration method, and phosphorus was determined by spectrophotometer (SpecorD250 plus, Analytic Jena, Germany) [23].

\subsection{Biological study.}

\subsubsection{Experimental animals and induction of diabetes.}

Forty-two male albino rats were used in this study and were acclimatized in the laboratory one week prior to the start of the experiment. Rats were fed (standard) commercial rat feed, and water was offered ad-libitum throughout the 45 days experimental period. At the beginning of the experiment, the average rats' weight was approximately $200 \mathrm{~g}$. For the induction of diabetes: rats were injected with $40 \mathrm{mg}$ streptozotocin (STZ) / kg body weight after fasting for $24 \mathrm{~h}$; after that, they received an orally 5\% sucrose solution for $48 \mathrm{~h}$ [24]. After $96 \mathrm{~h}$ of STZ injection, rats with moderate diabetes having a blood glucose range of above 250 $\mathrm{mg} / \mathrm{dl}$ were considered as diabetic rats and were used in the experiment.2.4.2. Experimental design.

A preliminary experiment was conducted to study the effect of Aloe vera gel and mango pulp on the biochemical analysis on the serum of diabetic rats. Rats were assigned randomly to five groups, each of six animals as follows:

Group 1: Normal control rats.

Group 2: STZ-induced diabetic control rats.

Group 3: Diabetic rats fed on commercial diet plus aloe vera gel extract $(0.5 \mathrm{ml} /$ day $)$.

Group 4: Diabetic rats fed on commercial diet plus mango pulp $(1.5 \mathrm{ml} /$ day $)$.

Group 5: Diabetic rats fed on commercial diet plus aloe-mango juice $25 \%$ (0.5 $\mathrm{ml}$ aloe gel: $1.5 \mathrm{ml}$ mango pulp/day). 
2.4.3. Blood collection and biochemical studies.

After 45 days, fasting blood samples were collected from the hepatic portal vein. Blood glucose, total cholesterol, triglycerides, HDL-c, AST, ALT, ALP, total protein, and albumin were analyzed in serum using Biochemical Blood Analyzer (ALFA WASSERMANN DIGNOSTIC TECHNOLOGYIES, LIC, ACE, Alera, USA). Low-density lipoprotein cholesterol (LDL-c) and very-low-density lipoprotein cholesterol (VLDL-c) were calculated according to [25]. The extend of MDA (lipid peroxidation product), which reacts with thiobarbituric acid reactive substances (TBARS) in acidic medium was measured in plasma calorimetrically at $534 \mathrm{~nm}$ according to the method of [26].

\subsection{Statistical analysis.}

Each experiment was done in triplicate, and the statistical analysis using analysis of variance (ANOVA) and Duncan's multiple range test for differences among different treatments were conducted using COSTAT statistical software comparisons between treatments that yielded a $(\mathrm{P}<0.05)$ were significant.

\section{Results and Discussion}

\subsection{Nutritional and antioxidant properties of mango and aloe vera.}

The results for mango and aloe vera nutritional composition, as well as their antioxidant properties, are shown in Table 1. Data show that mango pulp and aloe vera gel have very high moisture content (85 and 97.42\%, respectively). Mango pulp has a high antioxidant activity and contains approximately $549.6 \mathrm{mg}$ per $100 \mathrm{ml}$ and 9.65 and $23.18 \mathrm{mg}$ of flavonoids and phenols, respectively, which higher than that found in aloe gel. Mango is regarded as the king of all fruits, having a rich dietary source, antioxidants like vitamin E, C, A, and phenolic compounds $[27,28]$. According to [29], mango plays a key role in balancing a human's diet by supplying 64-86 calories of energy.

Table 1. Chemical analysis of some mango pulp and Aloe vera gel components.

\begin{tabular}{l|l|l} 
Analysis & Mango pulp & Aloe gel \\
\hline Moisture \% & 85.0 & 97.42 \\
\hline Fiber \% & 1.15 & 0.51 \\
\hline Ash \% & 1.61 & 0.64 \\
\hline Total antioxidant $\mathbf{( m g / 1 0 0 m l ) ~}$ & 549.6 & 196.8 \\
\hline Total flavonoids (mg/100ml) & 9.65 & 5.29 \\
\hline Total phenols (mg/100ml) & 23.18 & 11.83 \\
\hline Minerals (ppm) & \multicolumn{2}{l}{} \\
\hline Ca & 148.4 & 275.5 \\
\hline $\mathbf{P}$ & 176.1 & 40.4 \\
\hline $\mathbf{K}$ & 2053.2 & 1531.0 \\
\hline $\mathbf{M g}$ & 105.6 & 58.4 \\
\hline $\mathbf{C r}$ & 1.0 & 1.6
\end{tabular}

It is also obvious that mango pulp also has a high content of phosphorus, potassium, and magnesium (Table 1). Though, the content of other minerals such as calcium and chromium was lower than those present in Aloe gel. Rajendran et al. [30] analyzed trace elements in the Aloe gel and showed that $\mathrm{K}, \mathrm{Mg}, \mathrm{Zn}$, and $\mathrm{Na}$ concentrations exceeded $200 \mu \mathrm{g}$. The aforementioned findings are consistent with those reported by Pawar and Kamble [31], who reported that $\mathrm{K}$ and $\mathrm{Ca}$ are high-level macro-elements in Aloe vera leaves compared to other elements. 


\subsection{Sensory evaluation of mango-aloe vera juices.}

Sensory evaluation plays a crucial role in assessing any new products [32], and that is the only way to get the right opinion about the product's acceptance by the customer. Sensory evaluation was calculated for three focus of blending $(7.5,15$, and $25 \%)$ compared to control ( $0 \%$ aloe vera)(Table 2 ). The four criteria that were tested for contrasting treatments with others were taste, color, odor, and consistency. Based on those results, T2 (7.5\% aloe vera + mango) was found to be the best-mixed concentrate for all sensory aspects tested and to have significantly higher scores $(\mathrm{p}<0.05)$ for taste, color, odor, and consistency compared to T3 and T4.On the other hand, no significant differences in all sensory scores between T2 and the control group were observed.

Table 2. Organoleptic properties of different Aloe vera-mango juices.

\begin{tabular}{l|c|c|c|c} 
Nectar & Taste & Color & Odor & Consistency \\
\hline T1 (0\% Aloe) & $9.0 \pm 1.63^{\mathrm{a}}$ & $8.60 \pm 1.61^{\mathrm{a}}$ & $9.55 \pm 0.99^{\mathrm{a}}$ & $9.35 \pm 1.25^{\mathrm{a}}$ \\
\hline T2 (7.5\% Aloe) & $8.90 \pm 1.47^{\mathrm{ab}}$ & $9.10 \pm 1.47^{\mathrm{a}}$ & $9.30 \pm 1.05^{\mathrm{a}}$ & $9.00 \pm 1.24^{\mathrm{ab}}$ \\
\hline T3 (15\% Aloe) & $8.00 \pm 1.88^{\mathrm{b}}$ & $9.30 \pm 1.34^{\mathrm{a}}$ & $9.25 \pm 1.26^{\mathrm{a}}$ & $8.60 \pm 1.31^{\mathrm{b}}$ \\
\hline T4 (25\% Aloe) & $7.2 \pm 1.26^{\mathrm{c}}$ & $9.30 \pm 1.64^{\mathrm{a}}$ & $9.25 \pm 1.35^{\mathrm{a}}$ & $8.45 \pm 1.66^{\mathrm{b}}$
\end{tabular}

For treatment T4 containing $25 \%$ aloe vera, the significantly $(\mathrm{p}<0.05)$ lowest scores were reported. These results could be related to the bitter taste of Aloe Vera gel, which increased as the concentration of gel increased. While acceptance in juices with higher Aloe vera content was lower, the scores obtained were high and considered satisfactory. Boghani [5] showed that Aloe vera gives the highest hedonic in a ratio of 5 and $10 \%$ and can be successfully stored for in refrigerated condition for a period of 3 months without significant changes in sensory quality. At the same time, other authors concluded that aloe vera gel with acceptable quality could be consumed up to 25 percent [33].

\subsection{Minerals analysis of mango-aloe vera juices.}

Minerals play a key role in the different physiological functions of the body, particularly in the processes of construction and regulation. Table 3 data shows changes in the content of minerals $(\mathrm{Ca}, \mathrm{P}, \mathrm{K}, \mathrm{Cr}$, and $\mathrm{Mg}$ ) in mango juice mixed with different ratios of aloe vera gel. Mango juice contained $70.21 \mathrm{mg} / \mathrm{kg}$ of Ca while the supplementation with Aloe vera gel increased the calcium content in mango juice. Calcium content was significantly $(\mathrm{p}<0.05)$ highest in $25 \%$ aloe vera gel treatment $(167 \mathrm{mg} / \mathrm{kg})$. On the other hand, $7.5 \%$ Aloe vera gel showed a significant $(\mathrm{p}<0.05)$ minimum content in calcium. Data also revealed that there were no significant differences between mango juice without aloe vera (T1) and mango with 7.5\% aloe vera (T2) for $\mathrm{K}, \mathrm{P}$, and $\mathrm{Mg}$ contents. On the other hand, the contents of these minerals were significantly $(\mathrm{p}<0.05)$ decreased as the Aloe vera gel percentage increased. $\mathrm{K}$ is essential, and it plays a crucial role in cellular homeostasis [34]. $\mathrm{Mg}$ is essential for metabolism, immunologic reproduction, and connective tissue development [35]. $\mathrm{Mg}$ also plays a key function in the stabilization of lipid membranes, replication, and metabolic processes [36, 37].

Table 3. Minerals composition $(\mathrm{mg} / \mathrm{kg})$ of Aloe vera-mango nectars.

\begin{tabular}{l|c|c|c|c|c} 
Nectars & Ca & P & K & Cr & Mg \\
\hline T1 (0\% Aloe) & $70.21 \pm 0.01^{\mathrm{d}}$ & $110.3 \pm 1.28^{\mathrm{a}}$ & $1040 \pm 4.0^{\mathrm{a}}$ & $0.90 \pm 0.01^{\mathrm{b}}$ & $85.18 \pm 0.02^{\mathrm{a}}$ \\
\hline T2 (7.5\% Aloe) & $114.4 \pm 0.20^{\mathrm{c}}$ & $106.3 \pm 0.11^{\mathrm{ab}}$ & $1038 \pm 4.0^{\mathrm{ab}}$ & $0.95 \pm 0.01^{\mathrm{ab}}$ & $84.80 \pm 0.40^{\mathrm{ab}}$ \\
\hline T3 $(\mathbf{1 5 \%}$ Aloe) & $141.0 \pm 0.11^{\mathrm{b}}$ & $54.40 \pm 0.20^{\mathrm{c}}$ & $651.7 \pm 1.15^{\mathrm{c}}$ & $2.30 \pm 0.40^{\mathrm{a}}$ & $42.93 \pm 0.61^{\mathrm{c}}$ \\
\hline T4 (25\% Aloe) & $167.0 \pm 0.40^{\mathrm{a}}$ & $52.40 \pm 0.40^{\mathrm{d}}$ & $614.7 \pm 0.64^{\mathrm{d}}$ & $2.30 \pm 0.60^{\mathrm{a}}$ & $42.77 \pm 0.11^{\mathrm{c}}$
\end{tabular}


In comparison, gel chromium content was higher than control juice content, and juice chromium content was increased with the addition of aloe vera gel. For the $15 \%$ and $25 \%$ aloe gel procedures, chromium content increased with the addition of aloe gel to reach $2.3 \mathrm{mg}$. National Research Council (NRC) dietary intake of Chromium (III) limit, $50-200 \mu \mathrm{g} / \mathrm{day}$. Chromium (III) helps insulin maintain normal glucose levels. Chromium was found to diminish problems with insulin resistance [38].

\subsection{Antioxidant properties of aloe-mango juice blends.}

The Aloe-mango juice blends are shown in Table 4, the antioxidant activity of mango juice increased as the concentration of gel in the mixtures increased as the gel contains a variety of active compounds, i.e., phenolic compounds, vitamins, flavonoids and tannins [39-41] that have antioxidant properties. The total phenolic content of mango juice is reported as the equivalent of gallic acid and was found to be $6.64 \mathrm{mg} \mathrm{GAE} / 100 \mathrm{ml}$. However, the content of phenols was significantly influenced by the additional effect of aloe vera gel, the maximum content $(81.9 \mathrm{mg} / 100 \mathrm{ml})$ in the $25 \%$ aloe-mango juice sample, and the minimum $(76.8$ $\mathrm{mg} / 100 \mathrm{ml}$ ) in the $7.5 \%$ aloe-mango juice. Polyphenols are the most abundant antioxidants in the diet and are widespread components of fruits and vegetables [42]. Over the past 10 years, researchers and food manufacturers have been increasingly interested in the potential of polyphenols mainly because of their antioxidant properties, their abundance in our diet, and their role in the prevention of various oxidative stress-related diseases such as cancer, cardiovascular disease and neurodegeneration [43]. The same pattern in the content of phenols was observed in the juice for the flavonoids, and thus the highest flavonoid content (6.2 $\mathrm{mg} / 100 \mathrm{ml}$ ) was reported for 25 percent of Aloe supplemented mango juice. Dietary intake of flavonoids was associated with a lower risk of both heart disease and cancer, probably associated with the antioxidant activity of these compounds. While mango pulp has a high nutritional value, it can be recommended to complement Aloe vera gel to produce high-quality functional mango juice rich in some bioactive compounds. The functional food consists of conventional foods containing naturally occurring bioactive substances and bioactive enriched food (e.g., probiotics, antioxidants) [44]. Phytochemicals and functional foods constituents have been associated with the prevention and/or treatment of at least four of the leading causes of death in the U.S.A. cancer, diabetes, cardiovascular disease, and hypertension, along with the prevention and/or treatment of other medical diseases including neural tube defects [45].

\subsection{Biological study.}

3.5.1. Effect of oral administration of Aloe vera gel and mango pulp on some biochemical parameters of serum diabetic rats.

In diabetic patients, fruits can be excellent dietary components. This is due to their high nutritional values and their palatability, which increases compliance with patients. However, diabetic patients usually avoid sweet and juicy fruits, and those are recommended with significant restrictions by the physicians and dieticians.

Table 4. Antioxidant properties of Aloe-mango nectar blends.

\begin{tabular}{l|c|c|c|c} 
Phytochemicals & T1 & T2 & T3 & T4 \\
\hline Antioxidant activity (mg/100ml) & $151.8 \pm 1.10^{\mathrm{d}}$ & $346.5 \pm 0.64^{\mathrm{c}}$ & $376.8 \pm 1.11^{\mathrm{b}}$ & $380.6 \pm 0.20^{\mathrm{a}}$ \\
\hline Total phenols (mg/100ml) & $6.64 \pm 0.02^{\mathrm{d}}$ & $7.68 \pm 0.07^{\mathrm{c}}$ & $7.91 \pm 0.04^{\mathrm{b}}$ & $8.19 \pm 0.06^{\mathrm{a}}$ \\
\hline Total flavonoids (mg/100ml) & $1.16 \pm 0.01^{\mathrm{d}}$ & $5.81 \pm 0.07^{\mathrm{c}}$ & $6.04 \pm 0.02^{\mathrm{b}}$ & $6.2 \pm 0.06^{\mathrm{a}}$
\end{tabular}


Knowing their biological responses is important for rationalizing the advice of these fruits or their juices in diabetic patients.

The results of this investigation delayed both an acute hypoglycemic effect of mango pulp and the Aloe vera gel (Table 5). Nonetheless, Aloe gel oral administration reduces the serum glucose level in diabetic rats by around 62 percent compared to 48 percent in mango pulp. Upon administration of Aloe gel, liver enzyme, serum cholesterol, and HDL, and LDLcholesterol have returned to near-normal levels. The induction of diabetes by STZ injection caused a significant decrease in total protein. As shown in Table5, feeding rats with aloe gel showed no significant change in total protein and albumin compared to the normal control group. Historically, Aloe vera gel has been claimed to possess anti-diabetic activity. Aloe vera gel clinical trials were investigated, and results revealed that Aloe juice oral administration significantly reduced blood sugar and triglyceride levels in the treated patient groups [46]. The chemical constituents of Aloe gel were also demonstrated to be consisting of phenols and flavonoids. These constituents may be responsible for attenuating oxidative damage and decreasing glucose levels in diabetic rat serums. Besides, Phytosterols, one of the major components of Aloe vera has been found to reduce visceral fat accumulation, enhance hyperlipidemia, and hyperglycemia [47]. This reduction can be due to increase clearance and decreased production of the major transporters of endogenously synthesized cholesterol and triglycerides [48]. Research on immune stimulation in mice has shown that acemannan, a polysaccharide within Aloe, demonstrates dose-dependent activation of the macrophage. As administrated orally to rats, mannans also have been shown to prevent cholesterol absorption and lower cholesterol $[49,50]$. Aloe vera gel, however, has a bitter taste that can be irritating in the raw state and can be improved by adding some fruits like mango. In this research, we have attempted to combine both Aloe gel and mango juice to test the combination's effectiveness in lowering serum glucose, improving the use of Aloe gel in addition to good mango juice to diabetic patients with new safety products.

Table 5. Effect of Aloe vera and mango pulp treatments on biochemical analysis in rats with STZ-induced diabetes.

\begin{tabular}{l|c|c|c|c} 
Parameter & Normal & STZ-treated & STZ treated + Aloe gel & STZ treated + mange pulp \\
\hline Glucose (mg/dl) & $103.0 \pm 14.32^{\mathrm{d}}$ & $464.2 \pm 25.73^{\mathrm{a}}$ & $176.2 \pm 10.87^{\mathrm{c}}$ & $237 \pm 9.52^{\mathrm{b}}$ \\
\hline T-Cholesterol (mg/dl) & $119.1 \pm 9.91^{\mathrm{c}}$ & $224.2 \pm 6.91^{\mathrm{a}}$ & $124.3 \pm 5.99^{\mathrm{c}}$ & $139.2 \pm 4.05^{\mathrm{b}}$ \\
\hline Triglycerides (mg/ dl) & $67.33 \pm 10.10^{\mathrm{b}}$ & $113.5 \pm 12.20^{\mathrm{a}}$ & $73.02 \pm 7.32^{\mathrm{b}}$ & $77.50 \pm 17.30^{\mathrm{b}}$ \\
\hline HDL-c (mg/dl) & $50.05 \pm 6.00^{\mathrm{a}}$ & $36.36 \pm 5.54^{\mathrm{c}}$ & $48.61 \pm 2.46^{\mathrm{a}}$ & $44.37 \pm 3.46^{\mathrm{b}}$ \\
\hline LDL-c (mg/dl) & $55.59 \pm 10.97^{\mathrm{c}}$ & $165.1 \pm 10.83^{\mathrm{a}}$ & $61.08 \pm 8.35^{\mathrm{c}}$ & $79.32 \pm 7.77^{\mathrm{b}}$ \\
\hline VLDL-c (mg/dl) & $13.47 \pm 4.02^{\mathrm{b}}$ & $22.70 \pm 2.44^{\mathrm{a}}$ & $14.60 \pm 1.46^{\mathrm{b}}$ & $15.50 \pm 3.46^{\mathrm{b}}$ \\
\hline AST(U/I) & $37.00 \pm 5.16^{\mathrm{c}}$ & $92.75 \pm 13.10^{\mathrm{a}}$ & $39.75 \pm 1.91^{\mathrm{c}}$ & $69.75 \pm 9.98^{\mathrm{b}}$ \\
\hline ALT (U/I) & $30.25 \pm 3.0^{\mathrm{c}}$ & $87.00 \pm 7.30^{\mathrm{a}}$ & $33.50 \pm 2.0^{\mathrm{c}}$ & $81.00 \pm 4.32^{\mathrm{b}}$ \\
\hline ALP(U/I) & $113.0 \pm 10.32^{\mathrm{d}}$ & $170.2 \pm 5.74^{\mathrm{a}}$ & $127.0 \pm 8.48^{\mathrm{c}}$ & $140.2 \pm 8.38^{\mathrm{b}}$ \\
\hline Total protein (g/dl) & $7.00 \pm 0.36^{\mathrm{a}}$ & $3.75 \pm 0.73^{\mathrm{c}}$ & $6.50 \pm 0.78^{\mathrm{a}}$ & $5.55 \pm 0.93^{\mathrm{b}}$ \\
\hline Albumin (g/dl) & $4.02 \pm 0.44^{\mathrm{a}}$ & $2.83 \pm 0.55^{\mathrm{c}}$ & $3.90 \pm 0.36^{\mathrm{a}}$ & $3.40 \pm 0.63^{\mathrm{b}}$
\end{tabular}

3.5.2. Effect of oral administration of Aloe-mango juice on serum biochemical parameters.

For the normal and diabetic rats, blood glucose levels, total cholesterol, and triglycerides are listed in Table 6 . All treated groups showed a significant decrease in the serum glucose level compared with diabetic control. The decrease varies from 53.3\% in the Aloemango juice treatment (group 3) to $47.8 \%$ in the group received mango juice (group 5). Some elements, such as $\mathrm{Mg}$ and $\mathrm{Cr}$ in Aloe-mango juice (Table 4), may play an important role in the control and management of diabetes. Such elements are classified as hypoglycemic elements 
because they play a very important role in glucose metabolism. Chromium promotes insulin binding, and subsequently absorb glucose into the cell [51, 52]. Also, the lowering effect of glucose could be explained by the antioxidant activity of Aloe-mango juice, as it attenuated oxidative damage in the diabetic rat serum. A significant reduction in total cholesterol and lowdensity lipoprotein (LDL-cholesterol) with a concomitant increase in high-density lipoprotein (HDL-cholesterol) in animals administering aloe-mango juice as compared to other diabetic groups was also shown in the present investigation.

Table 6. Effects of administration of Aloe-mango juice on blood glucose and lipid profiles.

\begin{tabular}{l|c|c|c|c|c} 
Parameter & Group 1 & Group 2 & Group 3 & Group 4 & Group 5 \\
\hline Glucose (mg/dl) & $103 \pm 14.32^{\mathrm{d}}$ & $464.2 \pm 25.73^{\mathrm{a}}$ & $216.7 \pm 4.43^{\mathrm{c}}$ & $231.7 \pm 13.89^{\mathrm{b}}$ & $242.2 \pm 18.13^{\mathrm{b}}$ \\
\hline T-Cholesterol (mg/dl) & $119.1 \pm 9.91^{\mathrm{d}}$ & $224.2 \pm 6.91^{\mathrm{a}}$ & $145 \pm 5.64^{\mathrm{c}}$ & $159.7 \pm 6.45^{\mathrm{b}}$ & $155.3 \pm 11.24^{\mathrm{b}}$ \\
\hline Triglycerides (mg/ dl) & $67.33 \pm 10.1^{\mathrm{c}}$ & $113.5 \pm 12.20^{\mathrm{a}}$ & $80.55 \pm 6.55^{\mathrm{b}}$ & $85.73 \pm 17.27^{\mathrm{b}}$ & $81.0 \pm 16.81^{\mathrm{b}}$ \\
\hline HDL-c (mg/dl) & $50.05 \pm 6.00^{\mathrm{a}}$ & $36.36 \pm 5.54^{\mathrm{c}}$ & $44.67 \pm 2.77^{\mathrm{b}}$ & $41.14 \pm 7.34^{\mathrm{b}}$ & $42.17 \pm 3.61^{\mathrm{b}}$ \\
\hline LDL-c (mg/dl) & $55.59 \pm 10.97^{\mathrm{d}}$ & $165.1 \pm 10.83^{\mathrm{a}}$ & $84.16 \pm 4.64^{\mathrm{c}}$ & $101.4 \pm 10.17^{\mathrm{b}}$ & $96.95 \pm 13.97^{\mathrm{b}}$ \\
\hline VLDL-c (mg/dl) & $13.47 \pm 4.02^{\mathrm{c}}$ & $22.70 \pm 2.44^{\mathrm{a}}$ & $16.11 \pm 1.31^{\mathrm{b}}$ & $17.15 \pm 3.45^{\mathrm{b}}$ & $16.20 \pm 3.36^{\mathrm{b}}$
\end{tabular}

This abnormally high serum lipid level is due mainly to the uninhibited action of lipolytic hormones on deposits of fat [53]. Since polysaccharides are the major component of the gel [49], the combination of aloe gel and mango juice could increase its polysaccharide content, which has a healthy advantage in lowering serum cholesterol.

AST and ALT are essential hepatic metabolic enzymes that indicate liver damage by xenobiotics or other causes; when liver damage occurs, these enzymes are released from the liver into the blood serum. Consequently, the activities of AST and ALT are considered to indicate the degree of liver damage [54]. Data in Table 7 revealed significant differences in the levels of AST and ALT in all groups. Group 2 and group 5 showed an increase in the activities of AST and ALT as compared to those observed in other groups. A similar trend for ALP activity was reported. These findings indicate that these enzymes were released in far smaller amounts in the Aloe gel groups ( 3 and 4 ) than in the mango juice-treated group alone, and this finding may be attributed to the antioxidant properties of the gel extract. Chandan et al. [55] showed that aqueous extract of dried aerial parts of Aloe vera significantly reduced hepatic damage induced by carbon tetrachloride in mice and reversed certain biochemical parameters. The hepatoprotective action of the plant has been attributed to the protection of the liver enzyme via the gel's antioxidant properties [39].

Table 7. Effects of administration of Aloe-mango juice on serum biochemical parameters.

\begin{tabular}{l|c|c|c|c|c} 
Parameter & Group 1 & Group 2 & Group 3 & Group 4 & Group 5 \\
\hline AST(U/I) & $37 \pm 5.16^{\mathrm{e}}$ & $92.75 \pm 13.1^{\mathrm{a}}$ & $55.25 \pm 6.60^{\mathrm{c}}$ & $45.50 \pm 5.24^{\mathrm{d}}$ & $66.75 \pm 8.5^{\mathrm{b}}$ \\
\hline ALT (U/I) & $30.25 \pm 3.0^{\mathrm{e}}$ & $87 \pm 7.30^{\mathrm{a}}$ & $65.75 \pm 6.60^{\mathrm{c}}$ & $36.75 \pm 1.91^{\mathrm{d}}$ & $78.25 \pm 3.41^{\mathrm{b}}$ \\
\hline ALP (U/I) & $113 \pm 10.32^{\mathrm{d}}$ & $170.2 \pm 5.74^{\mathrm{a}}$ & $144 \pm 9.93^{\mathrm{b}}$ & $136.5 \pm 6.21^{\mathrm{c}}$ & $150 \pm 10.32^{\mathrm{b}}$ \\
\hline Total protein $(\mathbf{g} / \mathbf{d l})$ & $7.0 \pm 0.36^{\mathrm{a}}$ & $3.75 \pm 0.73^{\mathrm{c}}$ & $6.02 \pm 0.44^{\mathrm{b}}$ & $6.10 \pm 1.09^{\mathrm{b}}$ & $5.82 \pm 0.57^{\mathrm{b}}$ \\
\hline Albumin (g/dl) & $4.02 \pm 0.44^{\mathrm{a}}$ & $2.83 \pm 0.55^{\mathrm{c}}$ & $3.68 \pm 0.47^{\mathrm{ab}}$ & $3.75 \pm 0.47^{\mathrm{ab}}$ & $3.48 \pm 0.25^{\mathrm{b}}$
\end{tabular}

Table 7 also showed variations in total protein and albumin content either in control or in experimental groups within the sera of rats. Group 2 achieved the maximum decrease in the total protein and albumin contents, which accounted for 3.75 and $2.83 \mathrm{~g} / \mathrm{dl}$, respectively comparing to the normal control (7.0 and 4.02, respectively). Groups contain Aloe gel (3 and 4) maintains the protein and albumin contents in comparison with the mango juice group. The change in protein content might be due to the imbalance between the protein synthesis rate and the degradation in the liver [56]. 


\subsubsection{Body and relative organ weights.}

Data on the final body weight and relative liver and kidney weights of rats subjected to different treatments are shown in Fig 1. The animals treated with STZ seemed ill-looking with loss of their body weight due to protein wasting in a situation of unavailability of carbohydrate for use as an energy source [57]. Treatment of Aloe-mango juice (group 3) for 45 days significantly improved the bodyweight of rats in comparison with diabetic control. Moreover, the increase in weight in group 3 was also greater than that in groups 4 and 5 . The increase in body weight may be due to structural protein synthesis or glycemic control improvements [58].In the diabetic control group, an increase in relative liver weight was observed as opposed to a normal diabetic. The diabetic rats' given Aloe gel integrated their diets (groups 3 and 4) considerably decreased the liver enlargement. On the other side, Aloe gel or mango juice added feed administered by the relative kidney weight of the diabetic rats showed a substantial increase compared with non-diabetic rats. While, these values were lower than that in diabetic control rats (Fig 1), indicating the kidney ameliorative potential of gel or mango in diabetic by maintaining or regenerating the renal cell histo-architecture.
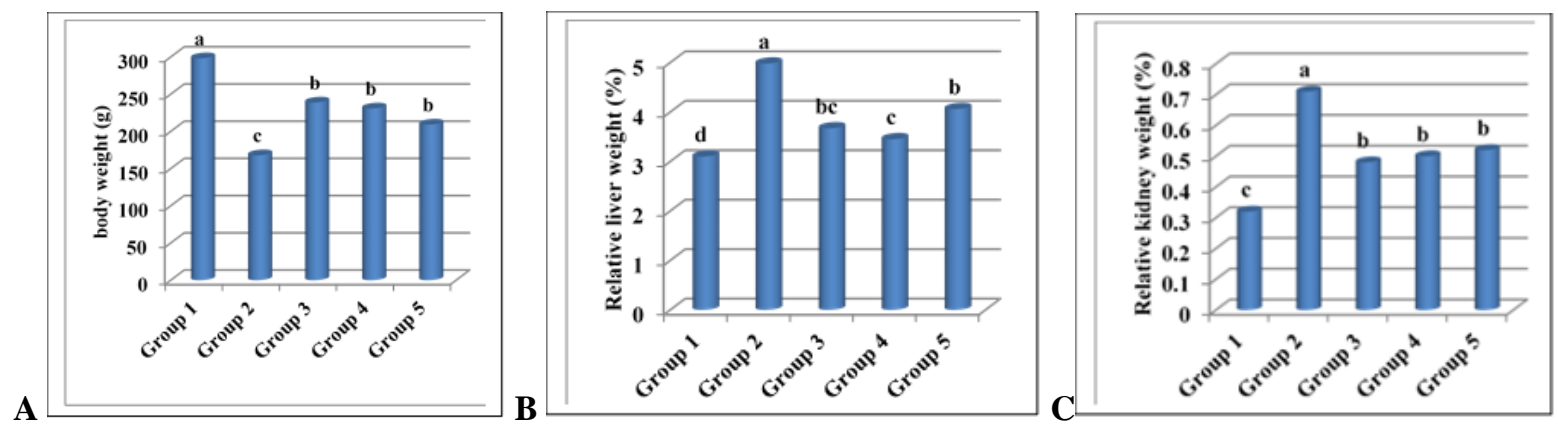

Figure 1. Bodyweight (A) and relative weight of liver (B) and Kidney (C) of rats exposed Aloe-mango juice, Aloe gel $(0.5 \mathrm{ml} / \mathrm{d})$ and mango juice $(1.5 \mathrm{ml} / \mathrm{d})$ (groups 3,4 and 5 , respectively) for 45 days in diets and normal group (1) and diabetic control group (2).

\subsubsection{Oxidative stress biomarker.}

During diabetes, there was a significant elevation of lipid peroxidation (MDA) compared to the normal group (Figure 2). Aloe gel treatment (group 4) prevented MDA changes that indicated the beneficial effect of Aloe gel and its protective efficacy against oxidative stress.

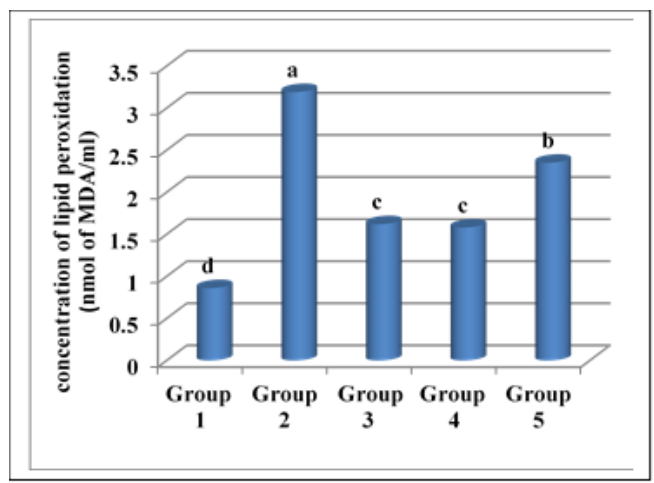

Figure 2. Changes in the levels of lipid peroxidation (MDA) in the serum of diabetic rats after 45 days of treatment with Aloe-mango juice, Aloe gel $(0.5 \mathrm{ml} / \mathrm{d})$, and mango juice $(1.5 \mathrm{ml} / \mathrm{d})$ (groups 3 , 4 and 5 , respectively). 
On the other hand, no significant variation in MDA level between groups 3 and 4 was observed. Haritha et al. [56] reported that Aloe gel extracts retarded the development of cataract in rats. Although multiple mechanisms may lead to these effects, the antioxidant effect of gel appears to be the predominant mechanism of action. Also, El- Sherbiny and Abdel-Aziz [57] observed that treatment with Aloe extracts increased antioxidant activity, as shown by a significant reduction in the lipid peroxidation product expressed as (MDA) in diabetic rats. They explained the antioxidant effect of Aloe gel due to a decrease in blood glucose levels, which prevents excessive free radicals from forming through different biochemical pathways. The observed decrease in MDA activity in diabetic rats treated with aloe-mango juice indicates the possible antioxidant effects of aloe gel that also apply to aloe-based juices.

\section{Conclusions}

It was conducted that the Aloe Vera gel provides a viable food-based and could be added to juices up to a level of $25 \%$ without affecting the acceptability. Supplementation of aloe gel resulted in considerable improvement of antioxidant capacity, phenols, and flavonoids content of mango juice. Aloe vera fresh juices and mango pulp exhibited a hypoglycaemic effect on their own. When offered in conjunction with each other ( $0.5 \mathrm{ml}$ aloe gel: $1.5 \mathrm{ml}$ mango pulp), glucose levels should decrease, retaining serum enzymes (AST, ALT, and ALP) and generating a significant reduction in MDA than mango juice alone that could be due to its high content of phenols and flavonoids. Other parameters, such as body weight and serum protein content, also showed improvement in aloe-mango juice. With the findings provided here, the Aloe-mango juice can be considered as a possible candidate for being part of a balanced diet and an alternative to diabetes juice. Future research should focus on the use of the Aloe gel in the preparation of various fresh juices and evaluation of the properties that promote their health.

\section{Funding}

This research received no external funding.

\section{Acknowledgments}

This research has no acknowledgment.

\section{Conflicts of Interest}

The authors declare no conflict of interest.

\section{References}

1. Ahlawat, K.S.; Khatkar, B.S. Processing, food applications and safety of Aloe vera products: a review. J. Food Sci. 2011, 48, 525-533, https://doi.org/10.1007/s13197-011-0229-z.

2. Kumar Kar, S.; Kanti Bera, T. Phytochemical constituents of Aloe vera and their multifunctional properties: a comprehensive review. International Journal of Pharmaceutical Sciences and Research. 2018, 9, 14161423. https://doi.org/10.13040/IJPSR.0975-8232.9.

3. Grover, J.K.; Yadav, S.; Vats, V. Medicinal plants of India with anti-diabetic potential. J. Ethnopharmacol 2002, 81, 81-100, https://doi.org/10.1016/S0378-8741(02)00059-4.

4. Malviya, N.; Jain, S.; Malviya, S. Antidiabetic potential of medicinal plants. Acta. Pol. Pharm 2010, 67, 113118, https://doi.org/10.1016/j.jep.2003.12.031.

5. Boghani, A.H. Development and storage studies of blended papaya-aloe vera ready to serve (RTS) beverage. J. Food Process Technology 2012, 3, 1-4, https://doi.org/10.4172/2157-7110.1000185.

6. Chand, P.; Pandey, N.; Naik, B.; Singh, A.; Kumar, V. Application of Aloe vera for the development of functional foods. The Pharma Innovation Journal 2019, 8, 621-625. 
7. Bafna, P.A.; Balaraman, R. Antioxidant activity of DHC-1, an herbal information, in experimentally induced cardiac and renal damage. Phytotherapy Research 2005, 19, 216-221, https://doi.org/10.1002/ptr.1659.

8. Khawandanah, J. Double or hybrid diabetes: A systematic review on disease prevalence, characteristics and risk factors. Nutrition and Diabetes. 2019, 9, 1-9. https://doi.org/10.1038/s41387-019-0101-1.

9. Wang, Z.; Wang, J.; Chan, P. Treating type 2 diabetes mellitus with traditional Chinese and Indian medicinal herbs. Evidence-Based Complementary and Alternative Medicine 2013, 2013, 1-7, https://doi.org/10.1155/2013/343594.

10. Bahrani, A.H.M.; Zaheri, H.; Soltani, N.; Kharazmi, F.; Keshavarz, M.; Karmalinajad, M. Effect of administration of psidium guava leaves on blood glucose, lipid profiles and sensitivity of the vascular mesenteric bed to phenylephrine in streptozotocin-induced diabetic rats. J. Diabetes Mellit 2012, 2, 138-145, http://dx.doi.org/10.4236/jdm.2012.21023.

11. Lin, L. Commonality between diabetes and Alzheimer's disease and a new strategy for the therapy. Clin. Med. Pathol. 2008, 1, 83-91, https://doi.org/10.4137/cpath.s667.

12. Raffone, A.; Travaglino, A.; Saccone, G.; D’Alessandro, P.; Arduino, B.; Mascolo, M.; De Pacido, G., Insabato, L.; Zullo, F. Diabetes Mellitus is associated with occult cancer in endomaterial hyperplasia. Pathology and Oncology Research. 2020, 26, 1377-1384. https://doi.org/10.1007/s12253-019-00684-3.

13. Li, D. Metformin as a antitumor agent in cancer prevention and treatment. J. Diabetes 2011, 3, 320-327, https://doi.org/10.1111/j.1753-0407.2011.00119.x.

14. Bana, S.; Gaur, P.; Kumar, N.; Goel, R. Diabetic neuropathy: a focus on management. Letters in Applied NanoBioScience 2020, 9, 853-860. http://doi.org/10.33263/LIANBS91.853860.

15. Chang, C.L.T.; Lin, Y.; Bartolome, A.; Chen, Y.C.; Chiu, S.C.; Yang, W.C. Herbal therapies for type 2 diabetes mellitus: chemistry, biology and potential application of selected plants and compounds. EvidenceBased Complementary and Alternative Medicine 2013, 2013, 1-33, https://doi.org/10.1155/2013/378657.

16. Gallagher, A.M.; Flatt, P.R.; Duffy, G.; Abdel-Wahab, Y.H.A. The effects of traditional anti-diabetic plants on in vitro glucose diffusion. Nutrition Research 2003, 23, 413-424, https://doi.org/10.1016/S02715317(02)00533-X.

17. Ran, S.; Gahlot, K.; Kumar, A. Experimental evidences of anti-diabetic activity of aqueous extract of cressa cretica L. On streptozotocin induced diabetes in rats. Letters in Applied NanoBioScience 2020, 9, 774-778. https://doi.org/10.33263LIANBS91.774778.

18. Sievenpiper, J.L.; Catherine, B.; Dworatzek, P.D.; Freeze, C.; Williams, S.L. Nutrition therapy. Candian Journal of Diabetes 2018, 42, S64-S79. https://doi.org/10.1016/j.cjd.2017.10.009.

19. Yang, J.; Lee, J. Application of sensory description analysis and consumer studies to investigate traditional and authentic foods: A review. Foods 2019, 8, 1-17. https://doi.org/10.3390/Foods8020054.

20. Peñarrieta, J.M.; Alvarado, J.A.; Bergenstahl, B.; Åkesson, B. Spectrophotometric methods for the measurment of total phenolic compounds and total flavonoids in foods. Bolivian Journal of Chemistry 2007, 24, 5-9.

21. Singleton, V.L.; Orthofer, R.; Lamuela-Raventos, R.M. Analysis of total phenols and other oxidation. Analysis of total phenols and other oxidation substrates and antioxidants by means of Folin-substrates and antioxidants by means of Folin- Ciocalteu reagent. Methods in Enzymology 299, 152-Ciocalteu reagent. Methods in Enzymology 1999, 299, 152- 178. https://doi.org/10.1016/S0076-6879(99)99017-1.

22. Prieto, P.; Pineda, M.; Aguilar, M. Spectrophotometric quantitation of antioxidant capacity through the formation of a phosphomolybdenum complex: Specific application to the determination of vitamin E. Analytical Biochemistry 1999, 269, 337-341, https://doi.org/10.1006/abio.1999.4019.

23. AOAC. Official Methods of Analysis of AOAC International. 19 th ed. Arlington: AOAC International. 2012. P.56.

24. Peschke, E.; Ebelt, H.; Bromme, H. J.; Peschke, D. Classical and new diabetogens: Comparison of their effects on isolated rat pancreatic islets in vitro. Cell Mol. Life Sci. 2000, 57, 158-164. Doi: 10.1007/s000180050505.

25. Friedewald, W.I.; Stewart, S.W.; Arnold, T.F. Estimation calculation of low density lipoprotein. Clin. Chem. 1972, 18, 499-505.

26. Onkawa, H; Ohishi, N.; Yagi, K. Assay for lipid peroxides in animal tissues by thiobarbituric acid reaction. Anal. Biochem. 1979, 95, 351-358, https://doi.org/10.1016/0003-2697(79)90738-3.

27. Barbosa, G.I.; Caballero, M.K.P.; Ledesma, N.; Sayago, A.S.G.; Garcia, M.M.L.; Bishopvon, W.E.J.; Montalvo, G.E. Changes in the nutritional quality of five Mangifera species harvested at two maturity stages. Journal of Science of Food and Agriculture 2017, 97, 4987-4994, https://doi.org/10.1002/jsfa.8377.

28. Liu, F.; Li, R.; Wang, Y.; Bi, X.; Liao, X. Effects of high hydrostatic pressure and high-temperature shorttime on mango nectars: Changes in microorganisms, acid invertase, 5-hydroxymethylfurfural, sugar, viscosity, and cloud. Innovative Food Science and Emerging Technologies 2014, 22, 22-30. https://doi.org/10.1016/j.ifset.2013.11.014.

29. Rathore, H.A.; Masud, T.; Sammi, S.; Soomro, A.H. Effect of storage on physico-chemical composition and sensory properties of mango (Mangifera indica L.) variety Dosehari. Pakistan Journal of Nutrition 2007, 6, 143-148.

30. Rajendran, A.; Narayanan, V.; Gnanavel, I. Study on the analysis of trace elements of Aloe vera and its biological importance. Journal of Applied Sciences Research 2007, 3, 1476-1478. 
31. Pawar, S.G.; Kamble, V.M. Quantitative assessment of mineral composition of Aloe vera (L.) Burm. f. leaves by ICP-MS and CHNS analyzer. International Journal of Science and Research 2015, 4, 1372-1376. www.ijsr.net.

32. Prescott, J.; Young, O.A.; O’Neill, L.O.; Yau, N.J.N. Motives for food choice: A comparison of consumers from Japan, Taiwan, Malatsia and New Zealand. Food Quality and Preference 2002, 98, 119-134, https://doi.org/10.1016/S0950-3293(02)00010-1.

33. Chaudhary, M.; Deen, B.; Gautam, D.K.; Mishra, K.K. Studies on development of squash from mango (Mangifera indica L.) pulp and Aloe vera (Aloe barbadensis Miller.) gel blend. Int. J. Curr. Microbiol. App. Sci. 2017, 6, 1962-1969. https:// doi.org/10.20546/ijcmas.2017.607.233.

34. Toyoshima, C.; Nakasako, M.; Nomura, H.; Ogawa, H. Crystal structure of the calcium pump of sarcoplasmic reticulum at $2.6^{\circ} \mathrm{A}$ resolution. Nature 2000, 405, 647-655, https://doi.org/10.1038/35015017.

35. Romani, A.M.P. Magnesium in health and disease. In: Interrelations between essential metal ions and human diseases. Sigel, A.; Sigel, H.; Sigel, R.K.O. Eds.; Springer, New York, 2013; pp. 50-70, https://doi.org/10.1007/978-94-007-7500-8_3.

36. Yang, W.; Lee, J.Y.; Nowotny, M. Making and breaking nucleic acids: two- $\mathrm{Mg}^{2+}$ - ion catalysis and substrate specificity. Mol. Cell 2006, 22, 5-13. https:// doi.org/10.1016/J.molcel.2006.03.013.

37. Payandeh, J.; Pfoh, R.; Pai, E.F. The structure and regulation of magnesium selective ion channels. Biochim. Biophys. Acta 2013, 1828, 2778-2792. https://doi.org/10.1016/j.bbamem.2013.08.002.

38. Balk, E.M.; Tatsioni, A.; Lichtenstein, A.H.; Lau, J.; Pittas, A.G. Effect of chromium supplementation on glucose metabolism and Lipids. Diabetes Care 2007, 30, 2154-2163. Doi: 10.2337/dc06-0996.

39. Hamman, J. Composition and applications of Aloe vera leaf gel. Molecules 2008, 13, 1599-1616, https://doi.org/10.3390/molecules13081599.

40. Radha, M.H.; Laxmipriya, N.P. Evaluation of biological properties and clinical effectiveness of Aloe vera: a systematic review. J. Tradit. Complement. Med. 2015, 5, 21-26, https://doi.org/10.1016/j.jtcme.2014.10.006.

41. Taukoorah, U.; Mahomoodally, M.F. Crude Aloe vera gel shows antioxidant propensities and inhibits pancreatic lipase and glucose movement In Vitro. Advances in Pharmacological Sciences 2016, 2016, 1-9. http://dx.doi.org/10.1155/2016/3720850.

42. Fang, Z., Zhang, M.; Sun, Y.; Sun, J. How to improve bayberry (Myrica rubra Sieb, et Zucc.) juice color quality: effect of juice processing on bayberry anthocyanins and polyphenolics. J. Agric. Food Chem. 2006, 54, 99-106, https://doi.org/10.1021/jf051943o.

43. Nejatzadeh-Barandozi, F. Antibacterial activities and antioxidant capacity of Aloe vera. Organic and Medicinal Chemistry Letters 2013, 3, https://doi.org/10.1186/2191-2858-3-5.

44. Choudhary, R.; Tandon, R.V. Consumption of functional food and our health concerns. Pakistan Journal of Physiology 2009, 5, 76-83. http://www.pps.org.pk/PJP/5-1/Raghuveer.pdf.

45. Goldberg, I. Reducing risk of cardiovascular disease. In: Functional Foods, Designer Foods, Pharmafoods, Nutraceuticals. $1^{\text {st }}$ ed.; Duthie, G.G., Brown, K.M., Eds.; Chapman and Hall, New York, NY, 1994; pp. 1938, https://doi.org/10.1007/978-1-4615-2073-3.

46. Mahdy, A.; Shehab, N.G. Hypoglycemic activity of Fagonia indica and Aloe vera in alloxan-induced hyperglycemia in mice. EC Pharmaceutical Science 2015, 239-244.

47. Misawa, E.; Tanaka, T.; Nomaguchi, K.; Yamada, M.; Toida, T.; Takase, M.; Iwatsuki, K.; Kawada, T. Administration of phytosterols isolated from Aloe vera gel reduce visceral fat mass and improve hyperglycemia in Zucker diabetic fatty (ZDF) rats. Obesity Res. Clin. Prac. 2008, 2, 239-245, https://doi.org/10.1016/j.orcp.2008.06.002.

48. Subbiah, R.; Ravi, K.; Sivagnanam, K.; Subramanian, S. Beneficial effects of Aloe vera leaf gel extract on lipid profile status in rats with streptozotocin diabetes. Clinical and Experimental Pharmacology and Physiology 2006, 33, 232-237, https://doi.org/10.1111/j.1440-1681.2006.04351.x.

49. Ni, Y.; Turner, D.; Yates, K.M.; Tizard, I. Isolation and characterization of structural components of Aloe vera L. Leaf pulp. Int. Immunopharmacol 2004, 4, 1745-1755. Doi: 10.1016/j.intimp.2004.07.006.

50. Sikarwar, M.S.; Patil, M.B.; Sharma, S.; Bhat, V. Aloe vera: plant of immortality. Intern. J. Pharma. Sci. Res. 2010, 1, 7-10.

51. Mohamed, E.A.K. Antidiabetic, antihypercholestermic and antioxidative effect of Aloe vera gel extract in alloxan induced diabetic rats. Aust. J. Basic Appl. Sci. 2011, 5, 1321-1327.

52. Lapenna, D.; Ciofani, G. Chromium and human low-density lipoprotein oxidation. Journal of Trace Elements in Medicine and Biology 2020, 59, 126411-126418. https://doi.org/10.1016/J.Jtemb.2019.126411.

53. Pushparaj, P.N.; Low, H.K.; Manikandan, J.; Tan, B.K.H.; Tan, C.H. Anti-diabetic effects of Cichorium intybus in streptozotocin-induced diabetic rats. J Ethnopharmacol 2007, 111, 430-434. https://doi.org/10.1016/j.jep.2006.11.028.

54. Zhang, J.; Wang, H.; Yan, X.; Zhang, L. Comparison of shortterm toxicity between Nano-Se and selenite in mice. Life Sci. 2005, 76, 1099-1109. https://doi.org/10.1016/j.Ifs.2004.08.015.

55. Chandan, B.K.; Saxena, A.K.; Shukla, S.; Sharma, N.; Gupta, D.K.; Suri, K.A.; Suri, J.; Bhadauria, M.; Singh, B. Hepatoprotective potential of Aloe barbadensis Mill. against carbon tetrachloride induced hepatotoxicity. J. Ethnopharmacol 2007, 111, 560-566, https://doi.org/10.1016/j.jep.2007.01.008. 
56. Mansour, S.A; Heikal, T.M.; Mossa, A.H.; Refaie, A.A. Toxic effects of five insecticides and their mixture on male albino rats. J. Egypt. Soc. Toxicol. 2008, 39, 85-94. www.jest.eg.net

57. Jacobson, T.A.; Miller, M.; Schaefer, E.J. Hypertriglyceridemia and cardiovascular risk reduction. Clinical Therapeutics 2007, 29, 763-777, https://doi.org/10.1016/j.clinthera.2007.05.002.

58. Eleazu, C.O.; Iroaganachi, M.; Okafor, P.N.; Ijeh, I.I.; Eleazu, K.C. Ameliorative potentials of ginger (Z. Officinale Roscoe) on relative organ weights in streptozotocin induced diabetic rats. International Journal of Biomedical Science 2013, 9, 82-90.

59. Haritha, K.; Ramesh, B.; Saralakumari, D. Effect of Aloe vera gel on antioxidant enzymes in streptozotocininduced cataractogenesis in male and female Wistar rats. Journal of Acute Medicine 2014, 4, 38-44. https://doi.org/10.1016/j.jacme.2014.01.005

60. El-Sherbiny, E.; Abdel-Aziz, S. Effect of gamma irradiation and Aloe vera on antioxidant status and thyroid functions in female rats. Ninth arab conference on the peaceful uses of atomic energy, Beirut, Lebanon, 2008, 1, 214-224.

61. Abd El-Kader, A.M.; Awadalla, E.A.; Gabr, S.A.; Nour, A.H. Evaluation of the histopathological and biochemical effect of Aloe vera aqueous extract on diabetes mellitus induced by streptozotocin in rats. Asian Journal of Pharmaceutical and Clinical Research 2019, 12, 38-45. http://dx.doi.org/10.22159/ajpcr.2019.v12i6.30995 